\title{
RANCANG BANGUN APLIKASI SISTEM PAKAR DIAGNOSA PENYAKIT ANEMIA DENGAN METODE FORWARD CHAINING BERBASIS ANDROID
}

\author{
Faisal Akib ${ }^{1}$ ),Ismail ${ }^{2}$ ) \\ 1,2 Jurusan Sistem Informasi Fakultas Sains dan Teknologi UIN Alauddin Makassar ${ }^{1,2} \mathrm{Jl}$. \\ H. M. Yasin Limpo No.36, Samata-Gowa, 92113, Telp/Fax: 0411-841879 \\ Email: faisal@uin-alauddin.ac.id
}

\begin{abstract}
Abstrak Kesehatan merupakan salah satu faktor penting untuk melakukan aktivitas sehari-hari. Namun, sebagian masyarakat tidak peduli terhadap kesehatan tubuhnya sehingga pada akhirnya banyak penyakit yang terlambat didiagnosis menyebabkan kondisi pada tahap yang serius. Salah satu penyakit yang dimaksud adalah anemia. Pada umumnya, jika masyarakat terkena gejala penyakit anemia maka akan pergi ke rumah sakit ataupun puskesmas terdekat untuk melakukan pemeriksaan. Namun disisi lain mereka harus mengorbankan waktu yang cukup banyak untuk hal tersebut. Untuk itu perlu dibuatkan aplikasi sistem pakar cek anemia bagi masayarakat sebagai sarana dalam mengatasi permasalahan tersebut
\end{abstract}

Kata Kunci : Aplikasi, Sistem Pakar, Anemia, Forward Chaining, Android

\section{PENDAHULUAN}

Kesehatan merupakan salah satu faktor penting untuk melakukan aktivitas sehari-hari. Namun, kebanyakan manusia tidak peduli terhadap kesehatan tubuhnya sehingga pada akhirnya banyak penyakit yang terlambat didiagnosis menyebabkan kondisi pada tahap yang serius. Salah satu penyakit yang dimaksud adalah anemia.

Nabi Muhammad saw bersabda "Orang mukmin yang kuat lebih baik dan lebih dicintai oleh Allah daripada orang mukmin yang lemah". Maksud dari hadits Nabi ini adalah orang mukmim yang kuat lebih baik dan dicintai oleh Allah swt karena dengan kekuatan itulah hidup manusia dapat dicapai. Memperhatikan dan menjaga kesehatan merupakan upaya yang harus selalu dilakukan. Islam mengenal satu konsep yang dinamik tentang kesehatan didalamnya tercakup pengertian tentang "SHIHHAH" yaitu keadaan jasmani yang memungkinkan seluruh anggota tubuh berfungsi dengan baik.

\section{METODE PENELITIAN}

Dalam rangka menyelesaikan rencana pembangunan sistem pakar diagnosa penyakit Anemia dengan metode Forward Chaining berbasis Android ini maka penulis telah melakukan penelitian berdasarkan metode yang dijalankan secara bertahap dan terencana

\section{HASIL DAN PEMBAHASAN}

Sistem Pakar Berbasis Web dan Mobile Web Untuk Mendiagnosis Penyakit Darah Pada Manusia Dengan Menggunakan 
Metode Inferensi Forward Chaining" oleh Silmi, dkk (2013). Aplikasi yang dirancang untuk menentukan jenis penyakit darah yang diderita. Aplikasi yang dirancang berbasis website dan mobile web.

Perbedaannya dengan aplikasi yang dirancang penulis yaitu pada objek penelitian dan arsitektur sistem. Penelitian sebelumnya mendiagnosis jenis penyakit darah yang diderita. Sedangkan penelitian penulis mengkhususkan diagnosa pada penyakit anemia dan aplikasi penulis dirancang untuk berjalan pada smartphone yang bersistem operasi android dengan metode Forward Chaining untuk melakukan diagnosa penyakit.

Penelitian selanjutnya dengan judul

"Perancangan Sistem Pakar Diagnosa

Penyakit Leukimia Dengan Metode Fordward Chaining” oleh Melisa (2015). Sistem pakar yang dirancang untuk mendiagnosa jenis-jenis penyakit Leukimia. Perbedaan dengan sistem yang dirancang oleh penulis yaitu terletak pada objek penelitian dimana penulis mendiagnosa jenis-jenis penyakit Anemia.

Penelitian selanjutnya dari Pratiwi (2015) dengan judul "Sistem Pakar Diagnosa Awal Penyakit Gigi dan Mulut Berbasis Android”. Sistem pakar ini hanya mendiagnosa penyakit awal pada gigi dan mulut. Perbedaan sistem yang dirancang oleh penulis adalah pada objek penelitian. Sistem pakar yang dirancang oleh penulis adalah untuk mendiagnosa penyakit anemia dengan metode forward chaining.

\section{Kegunaan Penelitian}

\section{a. Kegunaan bagi dunia akademik}

Sebagai konstribusi positif untuk kemajuan wawasan keilmuan teknologi informasi untuk pengembangan pada masa yang akan datang.

\section{b. Kegunaan bagi pengguna}

Sebagai media informasi dan
sistem pendamping untuk
mendiagnosa jenis-jenis penyakit
anemia yang biasa diderita oleh user.

\section{c. Kegunaan bagi mahasiswa}

$$
\begin{array}{cc}
\text { Dapat } & \text { mengembangkan } \\
\text { wawasan } & \text { keilmuan } \\
\text { dan } & \text { meningkatkan }
\end{array}
$$

pemahaman tentang struktur dan sistem kerja dalam pengembangan aplikasi pada sistem operasi android.

\section{Aplikasi}

Aplikasi merupakan perangkat lunak proses data yang berpacu pada sebuah komputasi. Aplikasi berasal dari bahasa inggris application yang berarti penerapan, lamaran ataupun penggunaan. Sedangkan secara istilah, pengertian aplikasi adalah suatu program yang siap untuk digunakan yang dibuat untuk melaksanakan suatu fungsi bagi pengguna jasa aplikasi serta penggunaan aplikasi lain yang dapat digunakan oleh suatu sasaran yang akan dituju. Sedangkan menurut kamus besar Bahasa Indonesia ( 2005 : 52 ), "Aplikasi adalah penerapan dari rancang sistem untuk mengolah data yang menggunakan aturan atau ketentuan bahasa pemrograman tertentu".

Defenisi aplikasi menurut para ahli:

1. Menurut Jogiyanto (1999), aplikasi adalah penggunaan dalam suatu computer, instruksi (instruction) atau pernyataan (statement) yang disusun sedemikian rupa sehingga komputer dapat memproses input menjadi output.

2. Menurut Harip Santoso (2015), aplikasi adalah suatu kelompok file (form, class, report) yang bertujuan untuk melakukan aktivitas tertentu yang saling terkait. 


\section{Anemia}

Anemia adalah suatu kondisi dimana terjadi penurunan kadar hemoglobin $(\mathrm{Hb})$ atau sel darah merah (eritrosit) sehingga menyebabkan penurunan kapasitas sel darah merah dalam membawa oksigen (Badan POM, 2011).

Anemia secara fungsional didefenisikan sebagai penurunan jumlah massa eritrosit (red cell mass) sehingga tidak dapat memenuhi fungsinya untuk membawa oksigen dalam jumlah yang cukup ke jaringan perifer (penurunan oxygencarrying capacity). Secara praktis anemia ditunjukkan oleh penurunan kadar hemoglobin, hematokrit atau hitung eritrosit (red cell count). Tetapi yang paling lazim dipakai adalah kadar hemoglobin, kemudian hematrokit. Harus diingat bahwa terdapat keadaan-keadaan tertentu dimana ketiga parameter tersebut tidak sejalan dengan masssa eritrosit, seperti pada dehidrasi, perdarahan akut dan kehamilan. Permasalahan yang timbul adalah berapa kadar hemoglobin, hematokrit atau hitung eritrosit sangat bervariasi tergantung pada usia, jenis kelamin, ketinggian tempat tinggal serta keadaan fisiologis tertentu seperti misalnya kehamilan.

Anemia bukanlah suatu kesatuan penyakit tersendiri (disease entity), tetapi merupakan gejala berbagai macam penyakit dasar (underlying disease). Oleh karena itu dalam diagnosis anemia tidaklah cukup hanya sampai kepada label anemia tetapi harus dapat ditetapkan penyakit dasar yang menyebabkan anemia tersebut.

\section{Kriteria Anemia}

Parameter yang paling umum dipakai untuk menunjukkan penurunan masa eritosit adalah kadar hemoglobin, disusul oleh hematokrit dan hitung eritrosit. Pada umumnya ketiga parameter ini tersebut saling bersesuaian. Yang menjadi masalah adalah berapakah kadar hemoglobin yang dianggap abnormal. Harga normal hemoglobin sangat bervariasi secara fisiologik tergantung pada umur,jenis kelamin, adanya kehamilan dan ketinggian tempat tinggal. Oleh karena itu perlu ditentukan titik pemilah (cut off point) dibawah kadar mana kita anggap terdapat anemia. Di negara barat kadar hemoglobin paling rendah untuk laki-laki adalah 14 g/dl dan 12 g/dl pada perempuan dewasa pada permukaan laut. Peneliti lain memberikan angka yang berbeda yaitu $12 \mathrm{~g} / \mathrm{dl}$ (hematokorit 38\%) untuk perempuan dewasa. $11 \mathrm{~g} / \mathrm{dl}$ (hematokorit 36\%) untuk perempuan hamil, dan $13 \mathrm{~g} / \mathrm{dl}$ untuk laki dewasa. g/dl (gram/100 militer darah). (Sumantri, 2008)

Tabel II.2 Kriteria Anemia

\begin{tabular}{|l|l|}
\hline \multicolumn{1}{|c|}{ Kelompok } & \multicolumn{1}{c|}{ Kriteria Anemia $(\mathbf{H b})$} \\
\hline Laki-laki dewasa & $<13 \mathrm{~g} / \mathrm{dl}$ \\
\hline Wanita dewasa tidak hamil & $<12 \mathrm{~g} / \mathrm{dl}$ \\
\hline Wanita hamil & $<11 \mathrm{~g} / \mathrm{dl}$ \\
\hline
\end{tabular}

Menurut WHO (Kusumadewi,

\section{Android}

Android merupakan sistem operasi berbasis linux yang bersifat terbuka (open source) dan dirancang untuk perangkat seluler layar sentuh seperti smartphone dan computer tablet. Android dikembangkan oleh Android, Inc,. dengan dukungan finansial dari google yang kemudian dibeli pada tahun 2005. Android dirilis secara resmi pada tahun 2007, bersamaan dengan didirikannya Open Handset Alliance.

Tampilan android didasarkan pada manipulasi langsung, menggunakan masukan sentuh yang serupa dengan tindakan di dunia nyata, seperti menggesek, mengetuk, mencubit dan membalikkan cubitan 
untuk memanipulasi objek di layar. Sifat android yang terbuka telah membuat bermunculannya sejumlah besar komunitas pengembang aplikasi untuk menggunakan android sebagai dasar proyek pembuatan aplikasi, dengan menambahkan fiturfitur baru bagi android pada perangkat yang secara resmi dirilis dengan menggunakan sistem operasi lain. (Salbino, 2014)

a. Komponen kebutuhan aplikasi

1) JDK (Java Development Kit)

JDK (Java Development Kit) merupakan lingkungan pemrograman untuk menulis program-program aplikasidanappletjava. JDK terdiri dari lingkungan eksekusi program yang berada di atas Operating

\section{Tabel dan Gambar}

\section{A.Tabel Penanganan}

Tabel IV-3. Struktur Tabel

Penanganan

\begin{tabular}{|l|l|l|l|}
\hline No & Nama Field & $\begin{array}{l}\text { Tipe } \\
\text { Data }\end{array}$ & Keterangan \\
\hline 1. & id & Int & $\begin{array}{l}\text { Primary Key, } \\
\text { Auto } \\
\text { Increment }\end{array}$ \\
\hline 2. & penanganan & Text & \\
\hline
\end{tabular}

B.Tabel Gejala

Tabel IV-4. Struktur

\begin{tabular}{|l|l|l|l|}
\hline No & $\begin{array}{l}\text { Nama } \\
\text { Field }\end{array}$ & $\begin{array}{l}\text { Tipe } \\
\text { Data }\end{array}$ & Keterangan \\
\hline 1. & Id & Int & $\begin{array}{l}\text { Primary Key, } \\
\text { Auto Increment }\end{array}$ \\
\hline 2. & Gejala & Text & \\
\hline
\end{tabular}

System source code dari java akan dikompilasi menjadi byte code yang dapat dimengerti oleh mesin. Selain itu JDK dapat membentuk sebuah objek code dari source code.

tabel yang digunakan dalam aplikasi ini

\section{A.Tabel Penyakit}

Tabel IV-1. Struktur

Tabel Penyakit

\begin{tabular}{|l|l|l|l|}
\hline No & Nama Field & $\begin{array}{l}\text { Tipe } \\
\text { Data }\end{array}$ & Keterangan \\
\hline 1. & Id & Int & $\begin{array}{l}\text { Primary Key, } \\
\text { Auto Increment }\end{array}$ \\
\hline 2. & penyakit & Text & \\
\hline
\end{tabular}

B.Tabel Penyebab

\begin{tabular}{|l|l|l|l|}
\hline No & $\begin{array}{l}\text { Nama } \\
\text { Field }\end{array}$ & Tipe Data & Keterangan \\
\hline 1. & id & Int & $\begin{array}{l}\text { Primary Key, } \\
\text { Auto Increment }\end{array}$ \\
\hline 2. & penyebab & Text & \\
\hline
\end{tabular}

\section{Perancangan Antarmuka (Interface)}

Perancangan antarmuka (interface) merupakan bagian penting dalam perancangan aplikasi, karena berhubungan dengan tampilan dan interaksi pengguna dengan aplikasi. Adapun perancangan antarmuka pada aplikasi ini yaitu sebagai berikut:

A. Perancangan Antarmuka Splash Screen

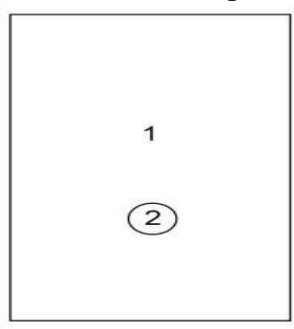

Gambar IV-13. Desain Antarmuka Splash Screen

Keterangan Gambar :

1) Gambar 
Akan dibuat dengan berisikan gambar splash screen aplikasi.

\section{2) Progress Bar}

$$
\text { Akan dibuat dengan }
$$

berisikan visualisasi proses

membuka aplikasi.

B. Perancangan Antarmuka Sliding Menu

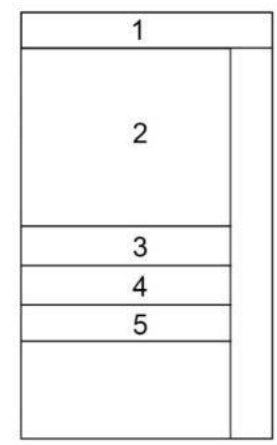

Gambar IV-14. Desain Antarmuka Sliding Menu

Keterangan Gambar :

1) Toolbar dan Teks

Akan dibuat dengan berisikan toolbar dan teks nama aplikasi.

2) Header

Akan dibuat dengan berisikan gambar header.

3) Teks

Akan dibuat dengan teks home.

4) Teks

Akan dibuat dengan berisikan teks Home

5) Teks

Akan dibuat dengan berisikan teks Info Anemia
6) Teks

Akan dibuat dengan beriskan teks Tentang

c. Perancangan Antarmuka Menu Beranda

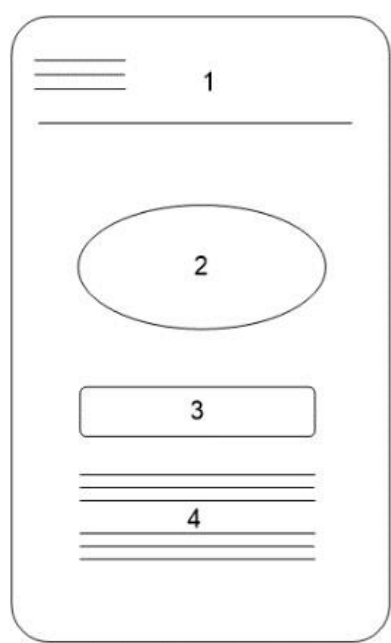

Gambar IV-15. Desain Antarmuka Beranda

Keterangan Gambar :

1) Toolbar dan Teks

Akan dibuat dengan

berisikan toolbar dan teks

beranda.

2) Gambar

Akan dibuat dengan berisikan gambar.

3) Button

Akan dibuat dengan berisikan Diagnosa

4) Teks

Akan dibuat dengan berisikan keterangan anemia

d. Perancangan Antarmuka Menu Mulai Diagnosa 


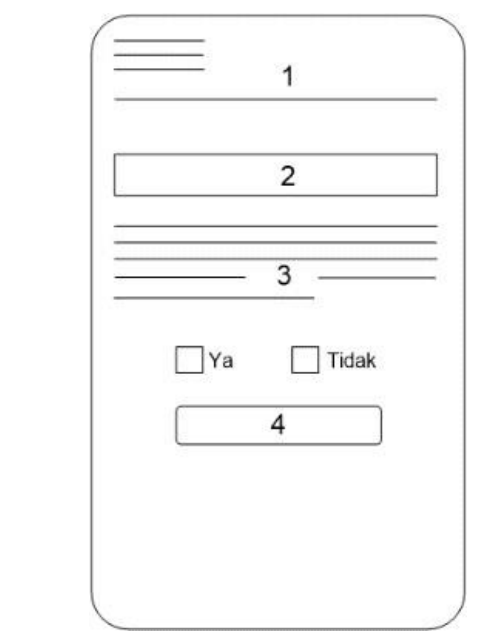

Gambar IV-16. Desain

Antarmuka Mulai Diagnosa

Keterangan Gambar :

1) Toolbar dan Teks

Akan dibuat dengan berisikan toolbar dan teks beranda.

2) Teks

Akan dibuat dengan berisikan teks pilihan gejala yang dialami.

3) Teks

Akan dibuat dengan berisikan pertanyaan.

4) Button

Akan dibuat dengan berisikan button selanjutnya.

e. Perancangan Antarmuka Hasil Diagnosa

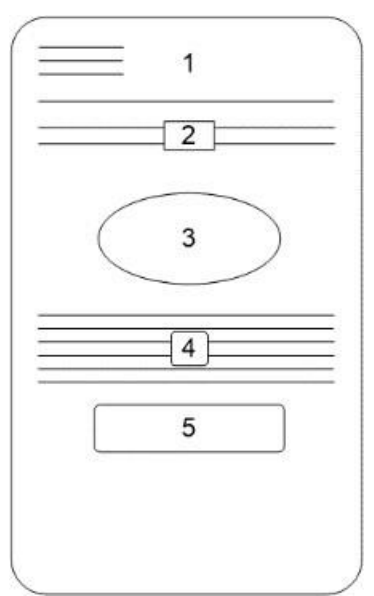

Gambar IV-17. Desain Antarmuka Hasil Diagnosa

Keterangan Gambar :

1) Toolbar dan Teks

Akan dibuat dengan berisikan toolbar dan teks mulai diagnosa.

2) Teks

Akan dibuat dengan berisikan teks Hasil Diagnosa

3) Gambar

Akan menampilkan gambar jenis anemia yang diderita.

4) Teks

Akan menampilkan keterangan jenis anemia yang diderita dan cara penanganannya.

5) Button

Akan dibuat dengan berisikan button selesai.

f. Perancangan Antarmuka Menu Info Anemia 


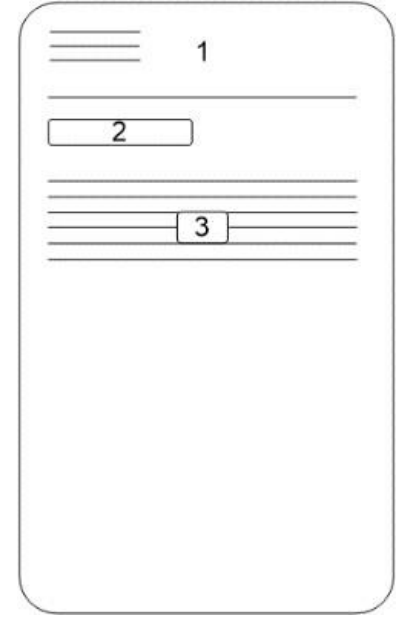

Gambar IV-18. Desain Antarmuka Info Anemia

Keterangan Gambar :

1) Toolbar dan Teks

Akan dibuat dengan berisikan toolbar dan teks mulai diagnosa.

2) Teks

Akan dibuat dengan berisikan teks Info Anemia

3) Teks

Akan dibuat dengan berisikan penjelasan anemia dan jenis anemia

g.Perancangan Antarmuka Menu Tentang

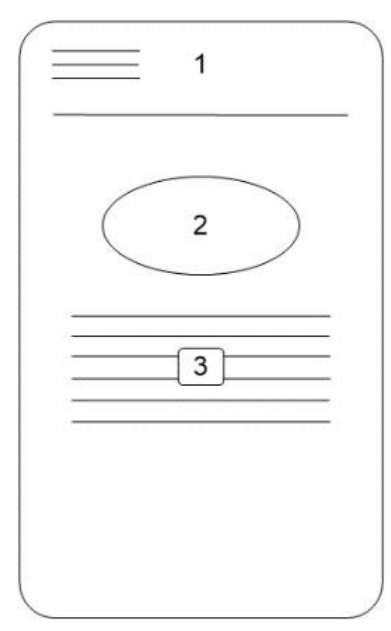

Gambar IV-19. Desain Antarmuka Menu Tentang

Keterangan Gambar :

1) Toolbar dan Teks

Akan dibuat dengan berisikan toolbar dan teks beranda.

2) Gambar

Akan dibuat dengan berisikan gambar aplikasi.

3) Teks

Akan dibuat dengan berisikan teks penjelasan aplikasi pakar anemia

\section{Antarmuka}

a) Antarmuka Splash Screen

Antarmuka splash screen akan menampilkan gambar splash screen aplikasi selama 3 detik. Setelah 3 detik akan muncul antarmuka menu utama. Berikut gambar dari antarmuka splash screen aplikasi. 


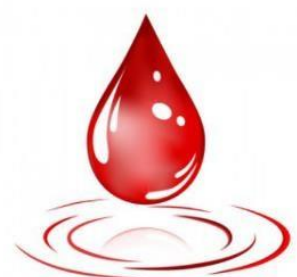

Gambar V.1. Antarmuka Splash Screen

b) Antarmuka Menu Home

Antarmuka menu home akan muncul ketika antarmuka splash screen telah selesai tampil. Berikut gambar dari antarmuka menu home.
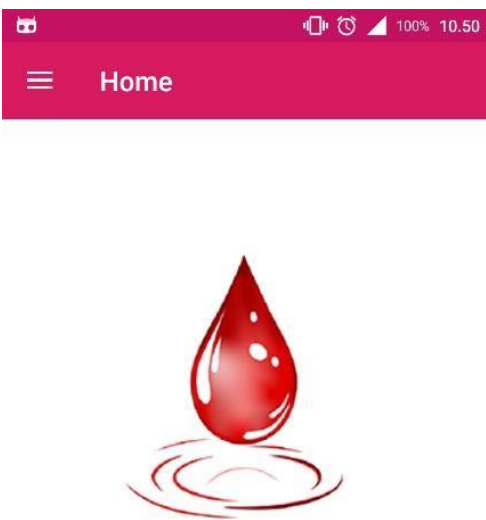

DIAGNOSA

Tekan tombol Diagnosa untuk mulai diagnosis.

Gambar V.2. Antarmuka Menu Utama

c) Antarmuka item Sliding Menu

Antarmuka menu utama terdiri item menu Home, Info Anemia, dan Tentang.

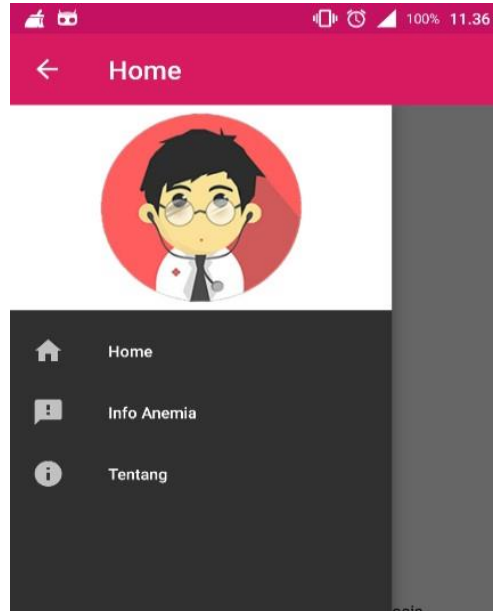

Gambar V.3. Antarmuka Item Sliding Menu

\section{d) Antarmuka Diagnosa}

Antarmuka ini berisikan pertanyaanpertanyaan mengenai gejala-gejala yang dialami oleh user kemudian dari jawaban user akan didapatkan sebuah hasil diagnosa.
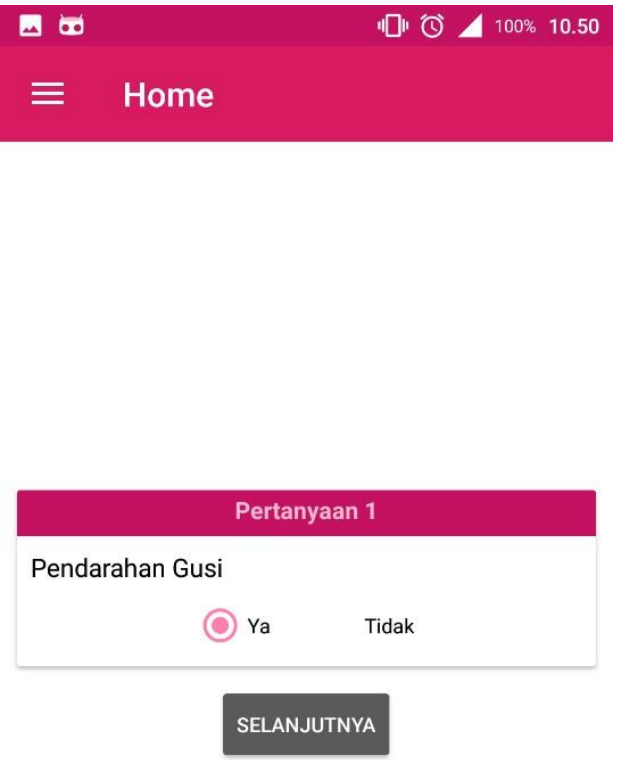

Gambar V.4 Antarmuka Diagnosa

e) Antarmuka Info Anemia Aplastik

Antarmuka info anemia Penyakit Aplastik ini berisikan dekripsi, penyebab dan cara penanganan anemia Penyakit Aplastik seperti pada gambar V.5 


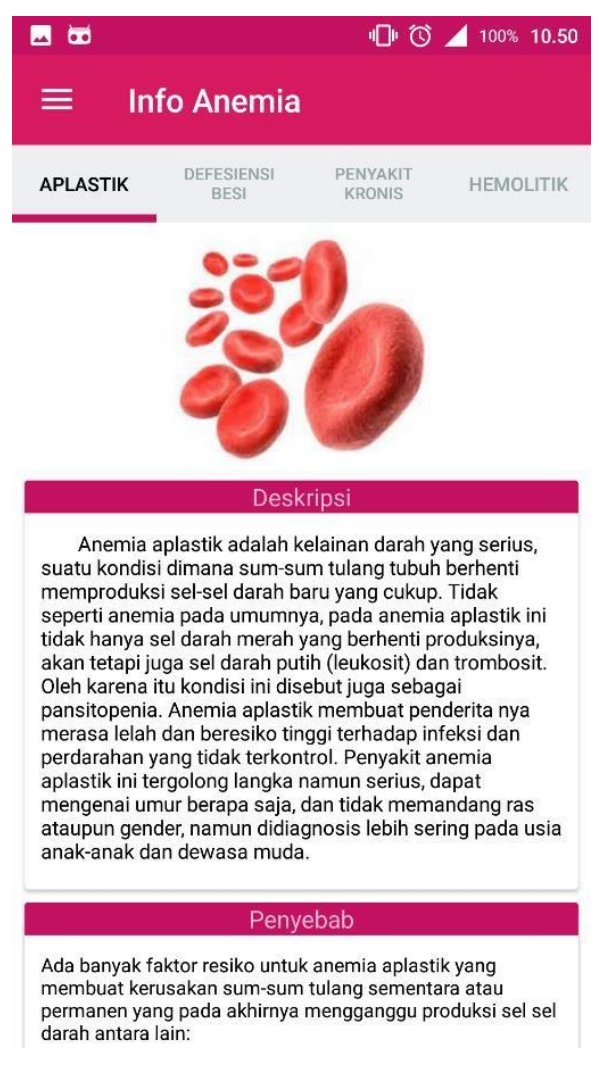

Gambar V.5 Antarmuka Info Anemia Aplastik

\section{f) Antarmuka Info Anemia Defesiensi Besi}

Antarmuka info anemia Defesiensi Besi ini berisikan dekripsi, penyebab, dan cara penanganan anemia Defesiensi Besi seperti pada gambar V.6

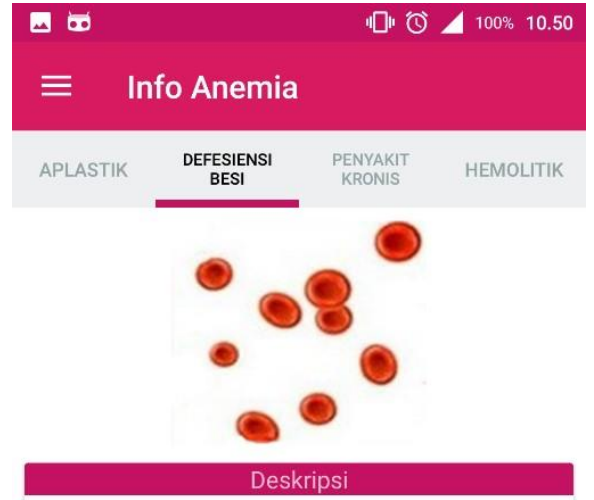

Anemia defisiensi besi adalah kondisi kekurangan nutrisi zat besi yang mengakibatkan penurunan jumlan sel darah merah. Zat besi diperlukan tubuh untuk menghasilikan komponen sel darah merah yang dikena sebagai hemoglobin. Hemoglobin di dalam sel dara merah dibutuhkan oleh tubuh untuk mengikat dan mengangkut oksigen dari paru-paru ke seluruh organ. Selain itu juga berperan dalam pembuangan karbon dioksida dari sel-sel tubuh di paru-paru. Jika tubuh manusia kekurangan sel darah merah, penyebaran oksigen dan pembuangan karbondioksida akan

terganggu.

Anemia jenis ini umum terjadi pada orang di segala usia, termasuk anak-anak, dengan penderita wanita lebi banyak dibanding pria. Sebagian besar kasus anemia terjadi di negara yang masih berkembang termasuk Indonesia. Anemia defisiensi besi adalah salah satu jenis anemia yang paling umum.

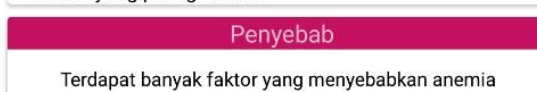

Gambar V.6 Antarmuka Info Anemia Defesiensi Besi

\section{g) Antarmuka Info Anemia Penyakit Kronis}

Antarmuka info anemia Penyakit Kronis ini berisikan dekripsi, penyebab dan cara penanganan anemia Penyakit Kronis seperti pada gambar V.7 


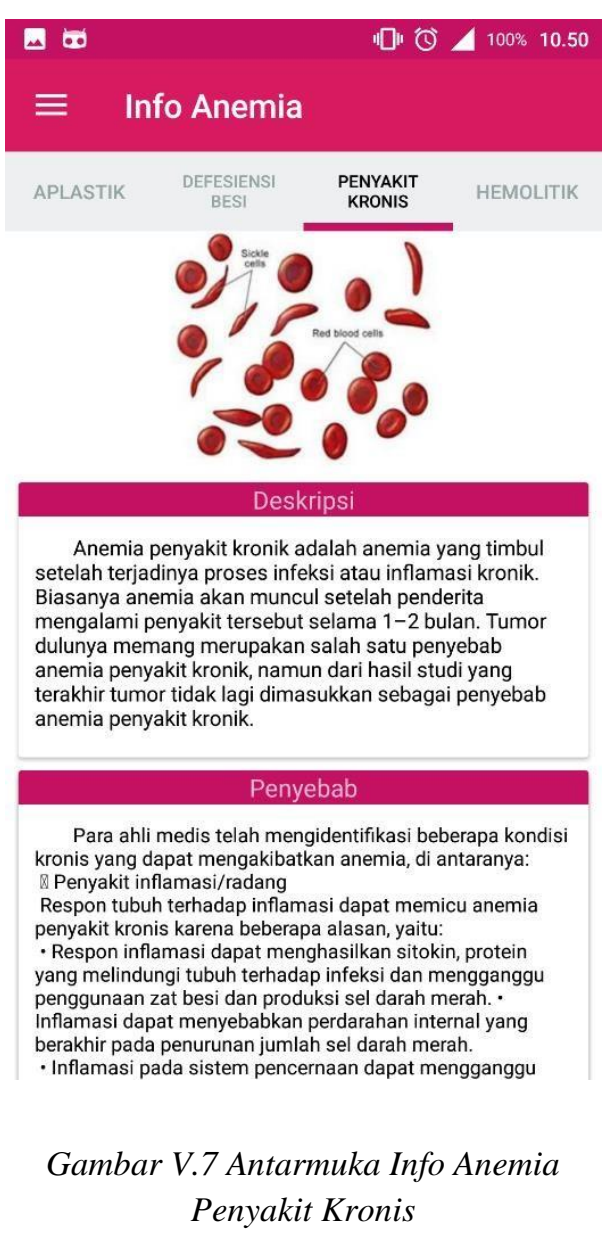

\section{h) Antarmuka Info Anemia Hemolitik}

Antarmuka info anemia Hemolitik ini berisikan dekripsi, penyebab, dan cara penanganan anemia Hemolitik seperti pada gambar V.8

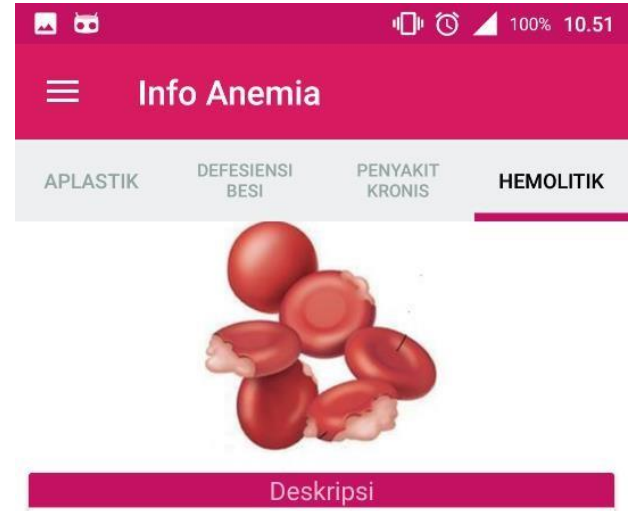

Anemia hemolitik adalah penyakit anemia yang terjadi ketika sel-sel darah merah mati lebih cepat daripada kecepatan sumsum tulang menghasilkan sel darah merah. Istilah ilmiah untuk penghancuran sel darah merah adalah hemolisis atau hemolitik (yang bersifat hemolisis). Jadi penyakit anemia yang disebabkan oleh umur sel darah merah yang singkat karena pecah sebelum waktunya kita sebut dengan anemia hemolitik.

Anemia hemolitik dapat menyebabkan berbagai masalah kesehatan, seperti kelelahan, nyeri, denyut jantung tidak teratur (aritmia), pembesaran jantung, dan gagal jantung. Penderita anemia hemolitik cenderung mud mudah lah karena tubuh mereka tidak menerima cukup asupan oksing dengan baik. Di sam adalah sesak napas, pusing, dan kulit pucat atau kuning. Jika tidak diobati, anemia dapat merusak hati dan organ utama lainnya akibat kurangnya asupan oksigen.

$$
\text { Penyebab }
$$

Penghancuran sel darah merah dapat disebabkan oleh kelainan darah, racun, atau infeksi. Lebih rinci, berikut

Gambar V.8 Antarmuka Info Anemia Hemolitik

\section{i) Antarmuka Menu Tentang}

Antarmuka menu Tentang memuat informasi tentang aplikasi. Berikut gambar dari antarmuka menu Tentang. 


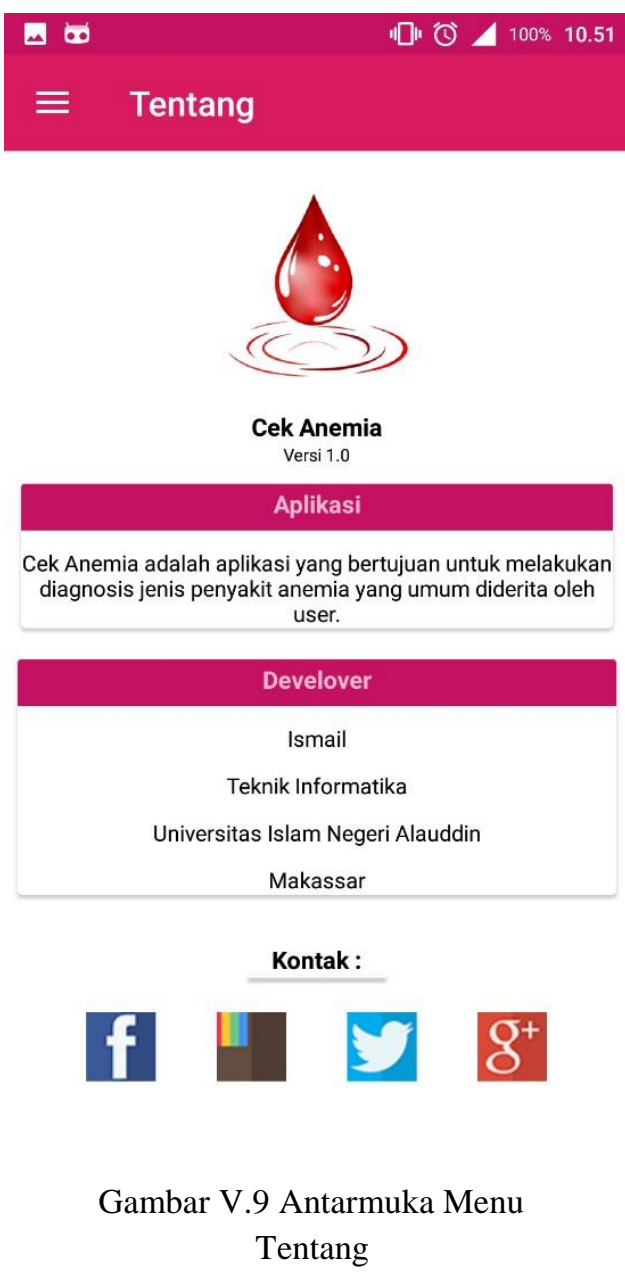

\section{KESIMPULAN}

Dari pembahasan yang telah dijelaskan pada bab-bab sebelumnya, dapat ditarik kesimpulan sebagai berikut :

1. Aplikasi ini memberikan kemudahan dalam penggunaan serta dapat digunakan dimana saja karena diaplikasikan dalam Smartphone Android.

2. Aplikasi ini tidak harus terhubung dengan jaringan internet untuk dapat di jalankan (offline).

3. Aplikasi ini merupakan aplikasi berbasis android yang dapat mendiagnosa dan menentukan jenis anemia yang diderita oleh user, dan juga penyebab anemia serta cara penanganan bagi user jika mengalami anemia.

4. Aplikasi sistem pakar ini menggunakan metode forward Chaining dalam menentukan kesimpulan.

\section{DAFTAR PUSTAKA}

Dorzie. Buku Pak Marimin. Blog Sirod. http://sirod.blogspot.com/2005/04/buku-pakmarimin.html. (7 Oktober 2015)
Fitriani. Makalah Gizi Anemia. http://vityup.blogspot.co.id/makalah-gizi-anemia/. (6 Januari 2016)

Hakim S., Rachmad. Mastering JavaTM Konsep Pemrograman dan Penerapannya Untuk Membuat Software Aplikasi. Jakarta : PT. Elex Media Komputindo, 2009.

Hartati, S., Iswanti, S. Sistem Pakar dan Pengembangannya. Yogyakarta: Graha Ilmu, 2008
Jogiyanto. Analisis dan Disain, Sistem Informasi:Pendekatan Terstruktur Teori dan Praktek Aplikasi Bisnis. Yogyakarta : Andi, 1999.

Jogiyanto. Analisis dan Desain. Yogyakarta : Andi, 2005.

Kusumadewi, Sri. Artificial Intelligence (Teknik Dan Aplikasinya). Yogyakarta : Penerbit Graha Ilmu, 2003.

Melisa, Perancangan Sistem Pakar Diagnosa Penyakit Leukimia Dengan Metode Fordward Chaining. Skripsi STMIK TIME Medan: Medan, 2015.

Mujiarto, Teguh. Donor Darah dalam Perspektif Islam. http://www.dakwatuna.com/2012/02/21/18830/don or-darah-dalamperspektifislam/\#axzz3wXLehBWl. (7 Januari 2016)

Muhammad, Abdullah. Dalam Tafsir Ibnu Katsir jilid 3. Bogor : Pustaka Imam Asysyafi'I, 2003.

Muhammad Silmi, dkk. Sistem Pakar Brbasis Web dan Mobile Web Untuk

Mendiagnosis Penyakit Darah Pada Manusia Dengan Menggunakan Metode Inferensi Forward Chaining. Skripsi Universitas Diponegoro: Diponegoro, 2013.

Nugroho, Adi. Analisis dan Perancangan Sistem Informasi dengan Metodologi Berorientasi Objek. Bandung : Informatika, 2005. 
